INDEPENDENT JOURNAL OF MANAGEMENT \& PRODUCTION (IJM\&P) http://www.ijmp.jor.br

v. 12, n. 9, Special Edition, December 21, IFLOG 2020

ISSN: 2236-269X

DOI: 10.14807/ijmp.v12i9.1635

\title{
A SIMULATION-BASED APPROACH TO IDENTIFY BOTTLENECKS IN THE BEARING MANUFACTURING PROCESS
}

Larissa Moreira Alves de Souza Souza Federal Institute of Education, Science and Technology, Brazil

E-mail: larissamoreira@hotmail.com

Adriano Maniçoba da Silva Instituto Federal de São Paulo - Campus Suzano, Brazil

E-mail: adrianoms@ifsp.edu.br

Julio Maria de Souza Federal Institute of Education, Brazil E-mail: juliomaria@ifsp.edu.br

Regis Cortez Bueno Federal Institute of Education, Science and Technology, Brazil E-mail: regiscb@ifsp.edu.br

Sivanilza Teixeira Machado Federal Institute of Education, Science and Technology, Brazil

E-mail: sivanilza@ifsp.edu.br

Wilson Yoshio Tanaka Federal Institute of Education, Science and Technology, Brazil E-mail:wtanaka@ifsp.edu.br

Submission: $3 / 29 / 2021$ Accept: 3/31/2021

\section{ABSTRACT}

Flexible manufacturing processes improve profitability and competitiveness for the company through an efficient process, with quality in a short time, and contribute to achieving low costs. One of the approaches that have been currently developed to improve the flexible manufacturing process is simulation. Simulation models consist of an assertive and powerful tool in strategic planning. It permits a controlled way of the company's reality so that it was possible to study and analyze the organization's current situation under several circumstances without altering the production's physical environment and involving low costs. Accordingly, this study's primary purpose was to develop a simulation model to verify bottlenecks' existence in the bearing manufacturing process. 
INDEPENDENT JOURNAL OF MANAGEMENT \& PRODUCTION (IJM\&P)

http://www.ijmp.jor.br

v. 12, n. 9, Special Edition, December 21, IFLOG 2020

ISSN: 2236-269X

DOI: 10.14807/ijmp.v12i9.1635

For this, a case study is presented, and it was used modeling/simulation with Arena Software as a research method. The results showed no bottlenecks in the manufacturing process.

Keywords: Process flow bearings; Flexible manufacturing system (FMS); Arena simulation software; Discrete-event simulation (DES)

\section{INTRODUCTION}

The manufacturing industry is recently growing in the international competition, which requires an efficient process, quality in a short time, and low costs. Many industries have used Flexible Manufacturing Systems to improve their profitability and competitiveness with technology. One flexible system is defined as a computer-controlled system for integrating a Numerically controlled machine and the material handling system (AndradeGutierrez, 2018; Kumar, 2015).

These flexibilities allow a company to quickly adapt to the market changes and focus on customer requirements and product quality increasing. In a continuously developing production environment, one of the significant manufacturing concerns is discovering how to enhance its production system performance to identify the operation's bottlenecks due to immediately affect the production rate (Motlagh et al., 2019).

In this context, a simulation is a tool for decision support that permits an analysis of a control strategy's variety (Campos, Encarnação \& Silva, 2019; Da Costa, Lúcio, Da Silva, \& Ferreira, 2017; Clementino, Da Silva, Da Silva, Tanaka \& Zampini, 2018; Dos Santos, Cajuí \& Da Silva, 2020; Pereira Júnior, Da Silva \& Moraes, 2020; Moraes \& Silva, 2021). It suggests an optimum solution for flexible manufacturing systems' real-time problems (Zywicki et al., 2020; Kumar et al., 2015; Morabito et al., 2010; Gavira, 2003).

This research aims to design a simulation model for the analyzed ball bearing manufacturing company to determine the process bottlenecks so that there is no human, material, financial waste. We identify that this company has discrete tie-ups many productive process steps that involve human resources and old equipment. The collected data applied the actual production times and flow, resources, and numbers to design the company's reality to be used in the simulation with Arena software.

The remainder of the paper is organized as follows. First, we present literature reviews about simulation methods and ball bearing manufacturing process. This is followed 
INDEPENDENT JOURNAL OF MANAGEMENT \& PRODUCTION (IJM\&P)

http://www.ijmp.jor.br

v. 12, n. 9, Special Edition, December 21, IFLOG 2020

ISSN: 2236-269X

DOI: 10.14807/ijmp.v12i9.1635

by methods and materials used to solve the problem. Section 4 shows the obtained analysis of results, and the last section presents the conclusion of this work.

\section{BACKGROUND ON SIMULATION AND ARENA SOFTWARE}

Theoretical fundamental is essential to limit the study's scope and provide a literature base that contributes to researchers (Cauchick et al., 2010). To explore the simulation process, it is essential to clarify that the market has been changed day by day. Companies become more competitive using business intelligence and simulation techniques to assemble systems and apply complex analysis (Harrel \& Tumay, 1995). Simulation makes real difficulties of the processes that could be productive or not, and the main objective is to analyze complex process under specifics condition informed by users (Um, Hyeonjae \& Lee, 2009)

Therefore, in a simulation process with total environment controlled, it is possible to show the company reality projected by computer and explore some behavior and features under several conditions without involving financial and time risks to a company (De Freitas Filho, 2001). Considering productive process, simulation is applying to predict, scale, and provide a balance in the production line and highlight that the simulation process affords a holistic view of the process (Figueredo, 2002).

In general, some parameters involve the simulation process during problem-solving modeling, such as distance, time, velocity, and available resources. These parameters provide a statistics report to assemble, identify, draft and measure resource utilization and each process time and improve them (Harrington \& Tumay, 2000).

Nowadays, there are many simulation software available to handle professionals and researchers applying the simulation process. Arena Simulation Software was published in 1993 by Systems Modeling Company, and nowadays, it became the tool more used to create a simulation model. According to de Freitas Filho (2001) and Kelton, Sadowski, and Swets (2010), Arena is Applied to creating several simulation models and new scenes in the Supply chain considering many factors such as raw material arrival, numbers of employers, human resources, process time, products diversity, bottleneck, as well as it is available much function that helps statistical analysis process to support the decision-making process and to optimize available resources.

The Input Analyser is a tool offered by Arena Simulation Software that allows determining the behavior curve, and it is used to predict some time process intervals. Input 
INDEPENDENT JOURNAL OF MANAGEMENT \& PRODUCTION (IJM\&P)

http://www.ijmp.jor.br

v. 12, n. 9, Special Edition, December 21, IFLOG 2020

ISSN: 2236-269X

DOI: 10.14807/ijmp.v12i9.1635

Analyser after simulation process shows the best mathematical model to describe the data behaviors inputted in the system, such as time of the data collected, and it could be used to model the graphic environment model (Prado, 2010).

\subsection{Ball bearing manufacturing}

The NSK Brasil catalog clarifies that the bearing that we have known nowadays was developed by the end of the XIX century and was obtained after the artisanal manufacturing process. A Bearing is one of the pieces more useful in machines due to allowing movement easily among parts and reducing friction. The deep groove ball bearing is the model commonly used because it shows many functions, and its characteristics consist of a contact point between ball bearing and raceway. In general, this kind of bearing does not handle oversized cargo. However, it operates under high rotation (Souza, 2019).

According to the SKF catalog (2015), the deep groove ball bearing is composted by four components such as outer and inner rings, balls, and cage. Each of these components is manufactured in different manufacturing lines and assembled in one complete bearing. Outer and inner rings result from forging, turning, heat treatment, and polishing processes. The first step to ring manufacture starts with a hot forging process with ingots under heating material to form outer and inner rings.

In the second moment, rings follow to turning process that makes first the side face of the piece to determine the width and after the raceway bearing (Santos et al., 2016). So, the company logo is stamped in products for market identification. The same authors explained that in the third step, pieces follow heat treatment to become more resistant. The heat treatment concerns heating rings over $800^{\circ} \mathrm{C}$ and applying the cooling process brusquely, heating over $150^{\circ} \mathrm{C}$, and cooling brusquely again. Finally, the rings follow the polishing process.

The steel ball results from a steel bar that is cut considering specific measures and follows to forging step. The forging process transform steel bars into balls, however, it is necessary to remove the excess steel material after the transformation process, so two steel discs are used. As well as the ring process, the balls follow heat treatment to become resistant (strong hardness) and finally to the polishing step.

Bearing applied in a typical work machine has included cages produced with sheet steel. These cages are modeled in flat rings from the stamping process and in corrugated shape to keep the balls in position. After the pressing step, the results are a hemispherical 
shape cage. Finally, the cage follows treatment before obtaining the final products. The last part of the bearing manufactured process is to assemble these pieces. The first step to assembly is to input the inner and outer ring together, and after the ball with the slight movement to the side. Finally, the balls are distributed in a cage due to the cage protects balls against drift out of position, and depend on the characteristics of the bearing, it could follow to lubrication, shielding, and sealing step.

\section{METHODS AND MATERIALS}

This research methodology has adopted the Arena software design environment in version 16 (2019) to provide executables discrete simulation models equipped with a processor Intel core i7 CPU dual-core 1.8GHz and $16 \mathrm{~GB}$ of RAM.

First, we understood the actual manufacturing problem and determined the aim of the model. It starts with time scheduling for data collecting, human and material resources. We collected data that involved the actual production times and flow, resources, and numbers to design the company's reality. Thus, the model has done and checked using the Arena Simulation Software for all the obtained data (BANKS, 1998).

Next, Interviews have accomplished with people responsible for the company's deep groove ball bearing product localized in Suzano. All the interviews acquired data was essential to model design that includes process flowchart, time and interval between them, scheduling stops the process, and available vital resources. We consider these crucial resources as staff quantity and occupation, raw material, product packing, and machinery. Sometimes, It was necessary to manually collect some information about the process because it has not been recorded.

We collected 96 comments through the inspection and packaging process time described in the discussion of the result. These comments were included on Arena Software Input Analyser to produce equations on that comments. It is essential to know that all collected data was presented to the supervisor to obtain validation.

\section{ANALYSIS OF RESULTS}

The first stage of the case study was to visit the company to understand the production process and thus be able to build a flowchart of the process. In an interview with the supervisor, it was defined that for this study, the final production process (assembly of the bearings), packaging, and transportation of the boxes until the warehouse would be considered. After the first visit, the flowchart was developed to validate this information, and 
DOI: 10.14807/ijmp.v12i9.1635

a second visit was carried out to verify if the model was reliable to reality. When a simulation model is created, the intention is to make it as accurate as possible from the real. However, by including details, the tendency is to increase the time for creating the model and, finally, its execution. Therefore, together with the supervisor, it was necessary to identify which characteristics and variables influenced the process to avoid unnecessary complexity. In Figure 1, it is possible to observe an overview of the process.

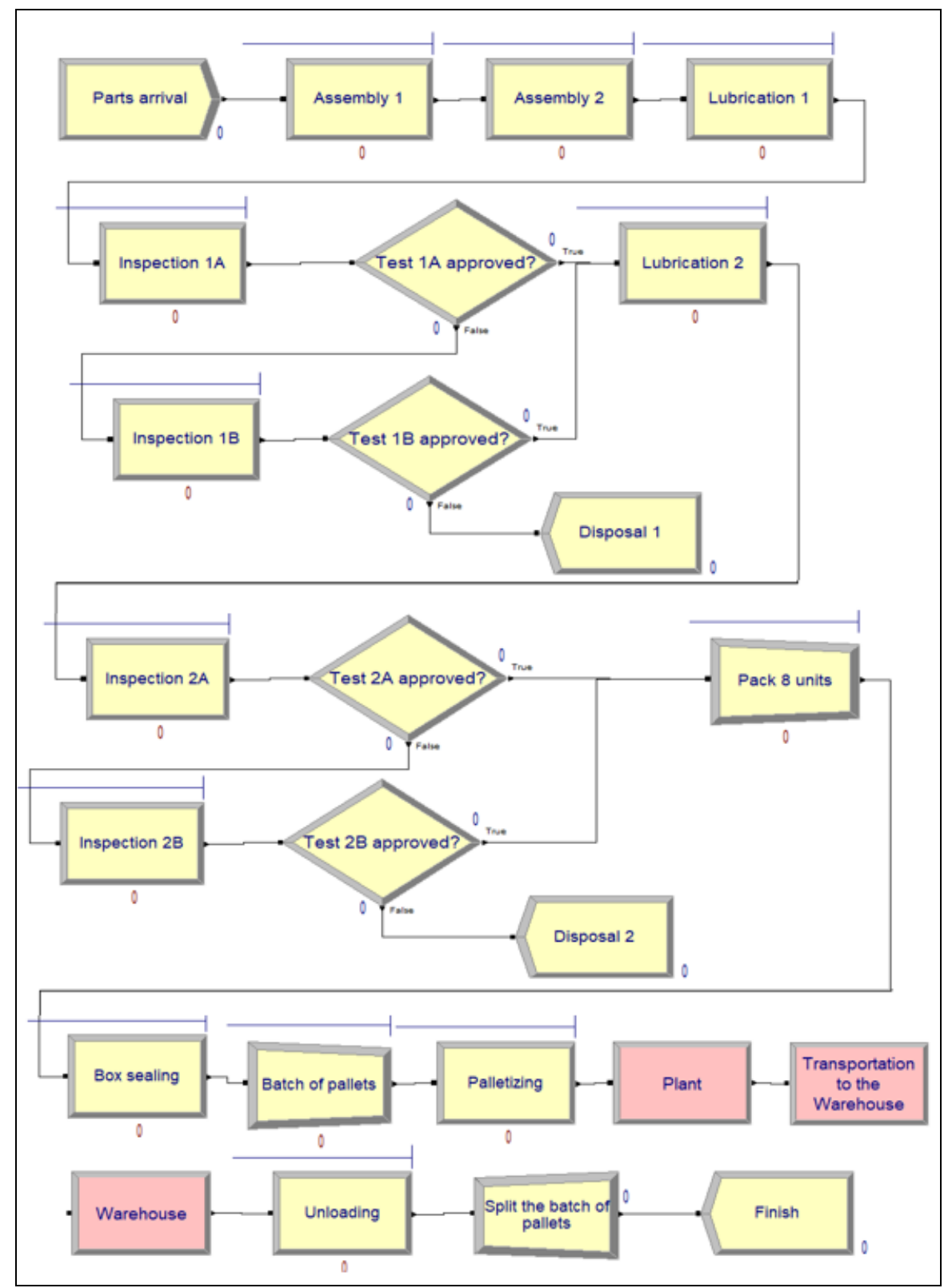

Figure 1: Overview of the process.

Source: Arena Software (2019)

The final production process for the deep groove ball bearing consists of joining the rings, the cage, and the balls previously produced, that is, assembling a bearing. According to the interview with the supervisor, the bearings pass through a production line, and for this 
reason, the time of the assembly, lubrication, and inspection processes carried out by machines are similar, not generating queues in the line. This time is 4.299 constant seconds. The parts (rings, spheres, and cage) arrive at the machine in 4.30 seconds, considering that the machine is automatically fed.

In the first assembly, the machine inserts the spheres into the rings. In the second assembly, a second machine fits the cage to the rings to fix them. Still, on the same production line, the bearing undergoes the first lubrication to meet the item's specificity through a shower of grease at the same time as the previous ones.

Then, to follow the quality standards, the first quality inspection is carried out, which will test the bearing's noise level employing a testing machine. Approximately $37 \%$ of the bearings manufactured are unsatisfactory in terms of noise. Whoever has a defect undergoes a second inspection made by the Quality Inspector, which evaluates whether it is a defect to the point of discarding the bearing or putting it back in the production process.

In this stage, generally, $48 \%$ of the bearings are discarded, and the rest is returned to the production process. Afterward, second lubrication is done through a second shower of grease just to ensure full application on the bearing. Finally, a final inspection is carried out to assess the bearing's rotation if it is rotating in perfect condition.

As with the previous inspection, non-approved bearings (about 35\%) go for a second inspection also made by the same Quality Inspector to check whether it is necessary to discard the bearing or not. In this stage, generally, 57\% of the bearings are discarded, and the rest goes back to the production process. Finally, the bearings are automatically packed in a box with 8, and an operator seals it.

Then, the same operator places 10 boxes on pallets and performs palletization, that is, organizes and fixes them so that transport does not fall. Now the process of transporting the pallets to the expedition takes place. A driver removes the pallet and, with a forklift, transports in a time with triangular distribution with parameters $(25,27,29)$. Finally, in the expedition, a second operator unloads the pallets. The processing times had to be collected using a sample through observation at random during the operators' workday. The constant production line times were informed through an interview with the PCP Supervisor.

In Table 1, it is possible to verify all processes, resources, times, and expressions generated by Arena's Input Analyzer and statistical characteristics that validate the collected values. 
INDEPENDENT JOURNAL OF MANAGEMENT \& PRODUCTION (IJM\&P)

http://www.ijmp.jor.br

v. 12, n. 9, Special Edition, December 21, IFLOG 2020

ISSN: 2236-269X

DOI: 10.14807/ijmp.v12i9.1635

Table 1: Process and times

\begin{tabular}{|c|c|c|c|c|c|c|}
\hline Process & Resource & $\begin{array}{c}\text { Constant } \\
\text { time }\end{array}$ & $\begin{array}{l}\text { Mean of } \\
\text { times } \\
\text { collected }\end{array}$ & $\begin{array}{c}\text { Standard } \\
\text { deviation of } \\
\text { times }\end{array}$ & Expression & $\begin{array}{c}\text { Kolmogorov- } \\
\text { Smirnov' test p- } \\
\text { value }\end{array}$ \\
\hline Parts arrival & - & 4.3 & - & - & - & - \\
\hline Assembly 1 & Assembler 1 & 4.299 & - & - & - & - \\
\hline Assembly 2 & Assembler 2 & 4.299 & - & - & - & - \\
\hline $\begin{array}{c}\text { Lubrification } \\
1\end{array}$ & $\begin{array}{l}\text { Grease } \\
\text { shower } 1\end{array}$ & 4.299 & - & - & - & - \\
\hline $\begin{array}{c}\text { Inspection } \\
1 \mathrm{~A}\end{array}$ & Noise test & 4.299 & - & - & - & - \\
\hline $\begin{array}{c}\text { Inspection } \\
1 \mathrm{~B}\end{array}$ & $\begin{array}{l}\text { Quality } \\
\text { inspector }\end{array}$ & - & 4.822 & 0.876 & $\begin{array}{c}2.5+4.5^{*} \\
\operatorname{BETA}(3.26,3.02)\end{array}$ & $>0.15$ \\
\hline $\begin{array}{l}\text { Lubrification } \\
\quad 2\end{array}$ & $\begin{array}{c}\text { Grease } \\
\text { shower } 2\end{array}$ & 4.299 & - & - & - & - \\
\hline $\begin{array}{c}\text { Inspection } \\
2 \mathrm{~A}\end{array}$ & $\begin{array}{l}\text { Rotation } \\
\text { test }\end{array}$ & 4.299 & - & - & - & - \\
\hline $\begin{array}{c}\text { Inspection } \\
2 \mathrm{~B}\end{array}$ & $\begin{array}{l}\text { Quality } \\
\text { inspector }\end{array}$ & - & 4.762 & 1.229 & $\operatorname{TRIA}(2,4.29,8)$ & $>0.15$ \\
\hline Box sealing & Operator 1 & - & 5.208 & 0.889 & $\begin{array}{c}\text { NORM(5.21, } \\
0.885)\end{array}$ & $>0.15$ \\
\hline Palletizing & Operator 1 & - & 5.404 & 1.631 & $\begin{array}{c}1+8^{*} \\
\operatorname{BETA}(2.73,2.23)\end{array}$ & $>0.15$ \\
\hline Unloading & Operator 2 & - & 3.712 & 1.095 & $\begin{array}{c}\text { NORM(2.86, } \\
0.814)\end{array}$ & $>0.15$ \\
\hline
\end{tabular}

According to Wayne (2000), the Kolmogorov - Smirnov test points to the equality of continuous probability distributions. In this case, all samples showed a p-value greater than 0.15 , that is, the samples are usable. To reduce variations and give veracity to the collected data, Arena was replicated 3 times for 8 hours of operation.

Finally, a report was generated presenting the results of the proposed model, in which, for analysis, some important points were emphasized. First, regarding the queues' waiting time. As expected, as it is a production line, the machine did not generate queues as it is always in motion, except for Lubrication 2 as it has bearings that have been waiting to return to the production line - if the bearing has gone to Inspection 1B and was approved, it returns to the line according to the availability of free space. Below, in Table 2, it is possible to check the queuing times of the model. 
INDEPENDENT JOURNAL OF MANAGEMENT \& PRODUCTION (IJM\&P)

http://www.ijmp.jor.br

v. 12, n. 9, Special Edition, December 21, IFLOG 2020

ISSN: 2236-269X

DOI: 10.14807/ijmp.v12i9.1635

Table 2: Model's waiting time (seconds)

\begin{tabular}{ccccccc} 
Process & Mean & $\begin{array}{c}\text { Half- } \\
\text { Width }\end{array}$ & $\begin{array}{c}\text { Minimum } \\
- \text { Mean }\end{array}$ & $\begin{array}{c}\text { Maximum } \\
-\end{array}$ & $\begin{array}{c}\text { Minimum } \\
\text { Value }\end{array}$ & $\begin{array}{c}\text { Maximum } \\
\text { Value }\end{array}$ \\
\hline Assembly 1 & 0 & 0 & 0 & 0 & 0 & 0 \\
Assembly 2 & 0 & 0 & 0 & 0 & 0 & 0 \\
Lubrification 1 & 0 & 0 & 0 & 0 & 0 & 0 \\
Inspection 1A & 0 & 0 & 0 & 0 & 0 & 0 \\
Inspection 1B & 3.8308 & 0.79 & 3.6237 & 4.1991 & 0 & 27.8525 \\
Inspection 2A & 0 & 0 & 0 & 0 & 0 & 0 \\
Inspection 2B & 2.6377 & 0.38 & 2.4772 & 2.7796 & 0 & 25.8296 \\
Lubrification 2 & 2.1513 & 0.25 & 2.0441 & 2.2434 & 0 & 13.3718 \\
Packing & 22.9127 & 1.08 & 22.489 & 23.3596 & 0 & 91.8481 \\
Box sealing & 0 & 0 & 0 & 0 & 0 & 0 \\
Batch of pallets & 237.2000 & 10.69 & 234.56 & 242.17 & 0 & 606.18 \\
Palletizing & 0 & 0 & 0 & 0 & 0 & 0 \\
Unloading & 0 & 0 & 0 & 0 & 0 & 0 \\
\hline
\end{tabular}

Another exciting piece of information to be addressed is the use of resources. According to Table 3, the processes carried out by the machines have a value above 0.82 on average, that is, the machines are being well used, considering that the purpose of the production line is to keep your machinery active as long as possible with the maximum possible utilization - the resource is not only $100 \%$ used, as with all machinery, it is necessary to carry out preventive maintenance and breaks when something is not in compliance, but considering this result and the conditions of the machines, in general, it resulted in higher utilization.

Also, in Table 3, information on the usage of human resources is provided, that is, it can be interpreted as the degree of occupation in their activities, being they, Quality Inspector, Operator 1, and Operator 2, in which it shows that the Inspector of Quality is with a much higher average compared to the Operators.

Table 3: Model's utilization

\begin{tabular}{ccccccc}
\hline Process & Mean & $\begin{array}{c}\text { Half- } \\
\text { Width }\end{array}$ & $\begin{array}{c}\text { Minimum } \\
\text { - mean }\end{array}$ & $\begin{array}{c}\text { Maximum } \\
\text { - mean }\end{array}$ & $\begin{array}{c}\text { Minimum } \\
\text { value }\end{array}$ & $\begin{array}{c}\text { Maximum } \\
\text { value }\end{array}$ \\
\hline Assembler 1 & 0.9998 & 0.00 & 0.9998 & 0.9998 & 0 & 1 \\
Assembler 2 & 0.9996 & 0.00 & 0.9996 & 0.9996 & 0 & 1 \\
Grease shower 1 & 0.9995 & 0.00 & 0.9995 & 0.9995 & 0 & 1 \\
Grease shower 2 & 0.8213 & 0.02 & 0.8148 & 0.8312 & 0 & 1 \\
Quality inspector & 0.7306 & 0.02 & 0.7227 & 0.7405 & 0 & 1 \\
Operator 1 & 0.1090 & 0.01 & 0.1065 & 0.1107 & 0 & 1 \\
Operator 2 & 0.0054 & 0.00 & 0.0054 & 0.0057 & 0 & 1 \\
Rotation test & 0.8212 & 0.02 & 0.8147 & 0.8311 & 0 & 1 \\
Noise test & 0.9993 & 0,00 & 0,9993 & 0,9993 & 0 & 1 \\
\hline
\end{tabular}


As shown in the analysis, the queues' waiting time (Table 2) and resource usage (Table 3) present no factors that could cause bottlenecks in the model. We conducted additional analysis by adding capacity to both machine and human resources and the batch processes, but the overall quantity of bearing pallets out of the system did not improve.

\section{DISCUSSION}

The average utilization of $94 \%$ of the equipment is an excellent use of resources, but at the same time, it can be a big problem, as there is no time available for the maintenance of the equipment, so there will be a need to stop the entire production line. Operators 1 and 2 have an average utilization of less than 11\% (0.109), and according to the production line supervisor, these operators are responsible for other activities in the company. Operator 1 is responsible for another 2 production lines, packing and palletizing the products, and operator 2 is responsible for unloading all pallets that arrive in the Shipping section, and these other activities were not considered in the modelling.

This study has shown that $73,06 \%$ utilization in quality inspection operation, demonstrating through the simulation that the inspection activity is not overloaded and 26.94\% of its time can be used for other activities. However, the standard quality inspector time used in this study was the stopwatch time for the activity's execution. Still, according to movement and time study, other factors must be considered when calculating the utilization of the human resources that may have contributed to the feeling that the quality inspector was overloaded.

These factors, called allowance factors, need to be added at the standard time of the human resources activities and can cause interruptions in production. They are classified into personal allowance and fatigue allowance. (Barnes, 1977; Martins \& Laugeni, 2005; Peinado \& Grael, 2007).

The personal allowance factor is a time set aside for the worker's personal needs, such as having water and go to the bathroom (Barnes, 1977). For an 8-hour work period without pre-established rest periods, the average worker will use 2 to 5\% (10 to $24 \mathrm{~min}$ ) per day for personal allowance. (Barnes, 1977; Peinado \& Grael, 2007). According to Martins and Laugeni (2005), the fatigue allowance factor considers the type of work and the environment in which this work is performed, for example, if the worker is carrying weight, works in excessive noise, low lighting, depending on the humidity of the air and the thermal comfort of the working environment. According to the working conditions, the fatigue allowance 
DOI: 10.14807/ijmp.v12i9.1635

factor may increase by $10 \%$, for light work in a good atmosphere, up to $50 \%$ of the time, for heavy work in inadequate conditions.

Other authors studies with process optimization simulation in production using the Arena software, used different allowance factors, such as Carneiro and Nazaré (2019), in their study demonstrated $99.57 \%$ of utilization of the labor in the assembly and gluing process, but they considered in the simulation parameters, 7 hours of work per day, although the daily work shift is 8 hours, as it was considered 1 hour for any rest and needs of employees, determining a total allowance factor of 12.5\%. Prado and Paixão (2019) and Montalvão and Oliveira (2020) considered a total allowance factor of 5\% and 20\%, respectively, these values being classified as light work and performed in an appropriate environment.

The allowance factor depends on the personal view, which requires a lot of motion and time study knowledge. According to data analysis and process in this article, it can be inferred that a total allowance factor of $12.5 \%$ for the quality inspector would be appropriate. Thus, the quality inspector's total utilization would be $85.56 \%$, with time available to carry out other activities.

\section{CONCLUSION}

This paper aimed to check if there are bottlenecks in the production line using software Arena simulation, from assembly to expedition. After the supervisor's information, we have created a model in the Arena software, reflecting the reality of the company because the data released in the modelling showed statistical characteristics that reinforce its reliability.

From the data presented, we have concluded that there is no bottleneck in the process. It is necessary to point out that factors such as the number of breaks and the occurrence of technical problems with the equipment were not considered in the created model. Thus, it ratified several points addressed in the literature review, in which the systems simulation allows the identification of bottlenecks and helps managers in decision making.

In future work, we suggested developing an improvement program because there is a failure rate of more than $35 \%$ in the production line and consider other external factors such as demand fluctuation and different production lines. 
DOI: 10.14807/ijmp.v12i9.1635

\section{REFERENCES}

Andrade-Gutierrez, E. S., Carranza-Bernal, S. Y., Hernandez-Sandoval, J., GonzalezVillarreal, A. J., \& Berber-Solano, T. P. (2018). Optimization in a flexible die-casting enginehead plant via discrete event simulation. International Journal of Advanced Manufacturing Technology, 95(9-12), 4459-4468.

Banks, J. (1998). Principles of simulation. In: Handbook of simulation: principles, methodology, advances, applications and practice. Nova York.

Barnes, R. M. (1977). Estudo de movimentos e de tempos: projeto e medida do trabalho. São Paulo. Edgard Blücher.

Campos, C. C. S., da Encarnação, E., \& da Silva, A. M. (2019). Simulação discreta aplicada à distribuição da alimentação escolar: Estudo de caso em uma escola pública. South American Development Society Journal, 5(14), 290.

Carneiro, P. H. W. \& Nazaré, T. B. (2019). Otimização de processo e arranjo físico utilizando o software Arena como ferramenta da simulação computacional. Anais do XXVI do Simpósio de Engenharia de Produção, Bauru, SP, Brasil.

Cauchick Miguel, P. A., Fleury, A., Mello, C., Nakano, D. N., \& Turrioni, J. B. (2010). Metodologia de pesquisa em engenharia de produção e gestão de operações. Rio de Janeiro: Elzevir.

Clementino, M. R., Silva, T. T. DA; Silva, A. M. DA; TanakA, W. Y., Zampini, E. D. F. (2018). Discrete simulation applied to a gas appliance company. Independent Journal of Management \& Production, 9(5),699.

Da Costa, L. S., Lúcio, W. D. S., Da Silva, A. M., \& Ferreira, W. D. P. (2017). Discrete simulation applied to the production process of electronic components. Independent Journal of Management \& Production, 8(5), 596-613.

Dos Santos, R. S. B., Cajui, R. M. F., \& Da Silva, A. M. (2020). Simulação a eventos discretos aplicada à gestão de filas em uma loja de tecidos. South American Development Society Journal, 6(17), 117.

Figueredo, S. R.A (2002). Introdução da Simulação como ferramenta de ensino e aprendizagem. Anais do XXII Encontro Nacional de Engenharia de Produção, Curitiba, PR, Brasil.

de Freitas Filho, P. J. (2001). Introdução à modelagem e simulação de sistemas: com aplicações em Arena. Visual Books..

Gavira, M. D. O. (2003). Simulação computacional como uma ferramenta de aquisição de conhecimento (Doctoral dissertation, Universidade de São Paulo).

Harrell, C., \& Tumay, K. (1997). Simulation made easy: a manager's guide. Engineering \& Management Press.

Harrington, H. J., \& Tumay, K. (2000). Simulation modeling methods (Vol. 8). McGraw Hill Professional.

Kelton, W.D., Sadowski, R.P., Swets, N.B. (2010). Simulation with Arena. 5 ed. New York: McGraw-Hill.

Kumar, G., \& Bisoniya, T. S. (2015). The simulation optimization of a flexible manufacturing system with Arena. Int J Eng Res Technol, 4, 755-760. 
Martins, P., Laugeni, F. (2005). Administração da Produção. São Paulo: Saraiva.

Montalvão, D. N. \& Oliveira, G. E. S. (2020, Outubro). Estudos de tempos e simulação computacional na fábrica de salgados delícias de Mainha. Anais do XL Encontro Nacional de Engenharia de Produção (ENEGEP 2020). Foz do Iguaçú, PR, Brasil.

Moraes, D. G., \& Silva, A. M. (2021). Simulação discreta aplicada à gestão de filas no varejo. Exacta, vol. 19, n.3.

Motlagh, M. M., Azimi, P., Amiri, M., \& Madraki, G. (2019). An efficient simulation optimization methodology to solve a multi-objective problem in unreliable unbalanced production lines. Expert Systems with Applications, 138, 112836.

NSK. Rolamentos. Disponível em:

<http://www.nsk.com.br/upload/file/Cat\%C3\%A1logo\%20Geral\%20NSK(1).pdf> Acesso em 23 de novembro de 2020.

Peinado, J., \& Graeml, A. R. (2007). Administração da produção: Operações industriais e de serviços. Unicenp.

Pereira Junior, J. V., Da Silva, A. M., \& Moraes, D. G. (2020). Discrete simulation applied to queue management in a supermarket. Independent Journal of Management \&

Production, 11(5), 1667-1684.

Prado, D. (2010). Usando o Arena em simulação. Nova Lima: INDG-Tecnologia e Serviços LTDA.

Prado, A. S. \& Paixão J. N. V. (2019, Novembro). Utilização de simulação computacional para análise de melhoria a serem aplicadas em uma linha de montagem de cadeiras de rodas. Anais do XXVI do Simpósio de Engenharia de Produção, Bauru, SP , Brasil.

Santos, A. P. A. D., Batista, F. R. R., Pinto, J. D. O., \& Benini, L. (2017). Processos de fabricação: rolamentos rígidos de esferas..

SKF (2020). Rolamentos de esferas, 2015. Disponível em: < https://www.skf.com/binaries/pub45/Images/0901d19680416a2b-10000_2-PT-BR---Rollingbearings_tcm_45-121486.pdf> Acesso em 23 nov. 2020.

Souza, G. (2020). Rolamento: o que é, quais são as suas aplicações e modelos existentes?. Disponível em: <https://blog.acoplastbrasil.com.br/o-que-sao-rolamentos/> Acesso em 23 nov. 2020.

Um, I., Cheon, H., \& Lee, H. (2009). The simulation design and analysis of a flexible manufacturing system with automated guided vehicle system. Journal of Manufacturing Systems, 28(4), 115-122.

Żywicki, K., \& Rewers, P. (2020). A simulation-based approach to study the influence of different production flows on manufacturing of customized products. Advances in Production Engineering \& Management, 15(4). 